\title{
Estimate of the (R)USLE rainfall erosivity factor from monthly precipitation data in mainland Spain
}

\author{
D. Hernando ${ }^{1}$, M.G. Romana ${ }^{1}$ \\ ${ }^{1}$ Department of Civil Engineering - Transport. Technical University of Madrid (UPM). Profesor Aranguren 3, 28040 Madrid, Spain.
}

e-mail addresses: davhernando@gmail.com (D.H); manuel.romana@upm.es (M.G.R)

Received: 14 May 2015 / Accepted: 13 April 2016 / Available online: 30 April 2016

\begin{abstract}
Calculation of the rainfall erosivity factor (R-factor) of the (R)USLE model requires continuous recording rain gauges, which may limit its use in areas without good temporal data coverage. In mainland Spain, the Nature Conservation Institute (ICONA) determined the Rfactor at few selected pluviographs, so simple estimates of the R-factor are definitely of great interest. The objectives of this study were: (1) to identify a readily available estimate of the R-factor for mainland Spain; (2) to discuss the applicability of a single (global) estimate based on analysis of regional results; (3) to evaluate the effect of record length on estimate precision and accuracy; and (4) to validate an available regression model developed by ICONA. Four estimators based on monthly precipitation were computed at 74 rainfall stations throughout mainland Spain. The regression analysis conducted at a global level clearly showed the modified Fournier index (MFI) ranked first among all assessed indexes. Applicability of this preliminary global model across mainland Spain was evaluated by analyzing regression results obtained at a regional level. It was found that three contiguous regions of Eastern Spain (Catalonia, Valencian Community and Murcia) could have a different rainfall erosivity pattern, so a new regression analysis was conducted by dividing mainland Spain into two areas: Eastern Spain and Plateau-lowland area. A comparative analysis concluded that the bi-areal regression model based on MFI for a 10-year record length provided a simple, precise and accurate estimate of the R-factor in mainland Spain. Finally, validation of the regression model proposed by ICONA showed that R-ICONA index overpredicted the R-factor by approximately $19 \%$.
\end{abstract}

Keywords: rainfall erosivity, R-factor, Universal Soil Loss Equation, modified Fournier index, soil erosion, Spain

Resumen

La necesidad de disponer de un registro continuo de la precipitación dificulta el cálculo del índice de erosión pluvial (factor R) del modelo (R)USLE en zonas sin un buen registro temporal. En la España peninsular, el Instituto para la Conservación de la Naturaleza (ICONA) determinó el factor $\mathrm{R}$ en un reducido número de pluviógrafos, por lo que es de gran interés disponer de una herramienta que permita estimar el factor R de manera sencilla. Los objetivos de este estudio fueron: (1) identificar un estimador del factor R en la España peninsular; (2) discutir la aplicabilidad de un único modelo de estimación global a partir de los resultados obtenidos a nivel regional; (3) analizar el efecto de la longitud del intervalo de cálculo en la precisión y exactitud de las estimaciones; y (4) evaluar el modelo de regresión disponible propuesto por ICONA. Para ello se calcularon cuatro estimadores basados en la precipitación mensual en 74 estaciones pluviométricas repartidas por la geografía peninsular. El análisis de regresión llevado a cabo demostró que el índice de Fournier modificado (MFI) es el mejor estimador. La aplicabilidad del modelo global generado inicialmente se evaluó mediante la comparación con resultados obtenidos a nivel regional. Se observó que tres comunidades autónomas del este peninsular (Cataluña, Comunidad Valenciana y Región de Murcia) presentaban un régimen de precipitaciones diferente al resto de la Península, por lo que se efectuó un nuevo análisis de regresión dividiendo el territorio en dos zonas: zona Este y resto de la península. A partir del estudio comparativo de los resultados, se concluyó que el modelo bizonal basado en el índice de Fournier modificado para un intervalo de 10 años permite obtener, de manera sencilla, una estimación lo suficientemente precisa y exacta del factor R en la España peninsular. Finalmente, se determinó que el modelo disponible propuesto por ICONA tiende a sobreestimar el factor $\mathrm{R}$ en aproximadamente un $19 \%$.

Palabras clave: erosión pluvial, factor R, Ecuación Universal de Pérdida de Suelo, índice de Fournier modificado, erosión del suelo, España 


\section{Introduction}

The Universal Soil Loss Equation (USLE) (Wischmeier and Smith, 1961, 1965, 1978) and its revised version (RUSLE) (Renard et al., 1991, 1997), commonly referred together as (R)USLE model, constitute a valuable tool for the study of soil erosion. (R)USLE is a simplistic empirical model that predicts long-term average annual soil loss based on six factors associated with rainfall erosivity, soil erodibility, topography (slope length and gradient), vegetation and management. Despite the simplicity of the (R)USLE model, its application is still limited in many regions because of the difficulty in computing the rainfall erosivity factor (Rfactor).

The R-factor for a single storm was defined as the product of the total kinetic energy (E) multiplied by the maximum 30-minute rainfall intensity $\left(\mathrm{I}_{30}\right)$ (Wischmeier, 1959). The $\mathrm{R}$-factor at a particular location is computed as the average of annual $\mathrm{E} \cdot \mathrm{I}_{30}$ values over long time intervals (over 20 years) to include apparent cyclical rainfall patterns (Wischmeier and Smith, 1978). Although several equations have been proposed for calculating the kinetic energy of a storm (Wischmeier and Smith, 1978; Brown and Foster, 1987), all of them require continuous recording rain gauges with time resolution of at least 15 minutes. This need for continuous recording makes it difficult to obtain the R-factor in some areas. This is the case for Spain, where rainfall data with good temporal coverage are still scarce.

There have been many attempts worldwide to establish correlations between the R-factor calculated by the prescribed method and more readily available rainfall data, such as daily and monthly precipitation (Renard and Freimund, 1994; Yu and Rosewell, 1996; Loureiro and Coutinho, 2001; Yu et al., 2001; Colotti, 2004; Diodato, 2004; Petkovšek and Mikoš, 2004; Diodato and Bellochi, 2007; Salako, 2008; Angulo-Martínez and Beguería, 2009; Bonilla and Vidal, 2011; Lee and Heo, 2011). Nonetheless, most of the obtained equations have limited application outside of the areas in which they were developed without a thorough validation analysis. In Spain, the Nature Conservation Institute (ICONA, 1988) performed a regression analysis that resulted in an isoerodent map and three equations to estimate the R-factor throughout the country. However, previous results reported by Hernando and Romana (2015) in central Spain suggested that the aforementioned equations may overpredict the Rfactor.

The objectives of this study were: (1) to identify a readily available estimate of the R-factor for mainland Spain; (2) to discuss the applicability of a single (global) estimate by means of comparison with regional results; (3) to evaluate the effect of record length on estimate precision and accuracy; and (4) to validate the existing regression model developed by ICONA.

\section{Material and methods}

\subsection{Rainfall erosivity estimators}

Based on the literature review, four estimators of rainfall erosivity were selected for this study: total annual rainfall (P), Fournier index (Fournier, 1960), modified Fournier index (Arnoldus, 1980) and a regression model proposed by the Spanish Nature Conservation Institute (ICONA, 1988). Other factors such as Hudson's KE $>25$ index (Hudson, 1971),

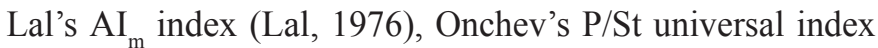
(Onchev, 1985), and Burst factor (Smithen and Schulze, 1982) were not considered since they still require continuous recording. In addition, Oliver's precipitation concentration index (Oliver, 1980) was discarded after poor results obtained in a preliminary screening. A further description of selected estimators is provided below.

Fournier (1960) found a high correlation between the total annual erosion and the distribution coefficient of rainfall or, most commonly named, Fournier index:

$$
F=\frac{p^{2}}{P}
$$

where $\mathrm{F}$ is the Fournier index, $\mathrm{p}$ is the maximum monthly precipitation and $\mathrm{P}$ is the total annual rainfall.

A major difference between calculation of the R-factor and $\mathrm{F}$ is that the latter only considers those storms out of the month with the highest precipitation within the denominator. For this reason, Arnoldus (1980) proposed a modification of the Fournier index so that the storms that occur outside the month of maximum rainfall increase the overall value of the index:

$$
M F I=\sum_{i=1}^{12} \frac{p_{i}^{2}}{P}
$$

in which MFI is the modified Fournier index, $p_{i}$ is the monthly rainfall and $\mathrm{P}$ is the total annual rainfall. Ferro et al. (1991, 1999) reported better estimates of the R-factor when the annual values of MFI were averaged over a period of several years.

In Spain, ICONA (1988) conducted research to evaluate the R-factor throughout the entire country. The research covered rainfall data from 1950 to 1985 and was based on the analysis of 162 pluviographs, supported by 809 additional rainfall stations due to the reduced number of continuous recording rain gauges. Regression analysis resulted in an isoerodent map and a regression model consisting of three equations to estimate the R-factor in the three zones that divided the country:

Zone 1:

$R_{\text {ICONA }}=e^{-0.034} \cdot P M E X^{1.314} \cdot M R^{-0.388} \cdot F_{24}^{0.563}$

Zone 2:

$R_{\text {ICONA }}=e^{-1.235} \cdot P M E X^{1.297} \cdot M R^{-0.511} \cdot M V^{0.366} \cdot F_{24}^{0.414}$ 
Zone 3:

$R_{\text {ICONA }}=e^{0.754} \cdot T_{2}^{1.331} \cdot T_{10}^{-0.028} \cdot F^{-0.482} \cdot P M E X^{1.288} \cdot M R^{-1.22} \cdot M V^{0.336} \cdot F_{24}^{0.8} \cdot e^{0.211 a-0.1577 b}$

where,

$\mathrm{R}_{\mathrm{ICONA}}$ is the rainfall erosivity index as estimated by ICO$\mathrm{NA}\left(\mathrm{MJ} \cdot \mathrm{cm} \cdot \mathrm{ha}^{-1} \cdot \mathrm{h}^{-1} \cdot \mathrm{year}^{-1}\right)$, PMEX is the maximum monthly precipitation (mm), MR is the total rainfall from October to May (mm), MV is the total rainfall from June to September $(\mathrm{mm}), \mathrm{F}$ is the Fournier index $(\mathrm{mm}), \mathrm{F}_{24}$ is the ratio of the square of the maximum annual rainfall in 24 hours $(\mathrm{mm})$ to the sum of the maximum monthly rainfall in 24 hours $(\mathrm{mm})$ :

$$
F_{24}=\frac{\left(P_{24 h, \text {, nnпual }}\right)^{2}}{\sum_{i=1}^{12} P_{24 h, i}}
$$

$\mathrm{T}_{2}$ represents the maximum annual rainfall in 24 hours for a 2-year recurrence interval, $\mathrm{T}_{10}$ is the maximum annual rainfall in 24 hours for a 10-year recurrence interval, and a and $\mathrm{b}$ are two parameters that can take the values of zero or one depending on the location.

Annual values for the period covered by each rainfall station were calculated for the four estimators. A series of values for each estimator were then obtained by averaging annual values over time intervals. These series were used to evaluate the effect of record length through regression analyses. The effect of record length on each estimator was studied using the following time intervals: 1, 2, 5, 10, 15 and 20 years, as described by Eq. 7:

$$
X_{N}=\frac{1}{N} \sum_{i=1}^{N} X_{i}
$$

where $\mathrm{X}_{\mathrm{N}}$ represents the value of the estimator (R-ICONA, $\mathrm{P}, \mathrm{F}$ and MFI) for a record length of $\mathrm{N}$ consecutive years, and $\mathrm{X}_{\mathrm{i}}$ is the annual value of the estimator in year i. Eq. 7 was applied to all consecutive 1, 2, 5, 10, 15 and 20-year intervals within the period covered by each rainfall station.

\subsection{Study area}

This study covered mainland Spain, which refers to the regions located in the Iberian Peninsula. It is bordered to the north by the Cantabrian Sea and France, to the east and south by the Mediterranean Sea, and to the west by the Atlantic Ocean and Portugal. The total area of mainland Spain is $492,175 \mathrm{~km}^{2}$, divided into 15 administrative regions (Fig. 1). The orography is dominated by a central vast plateau around $600 \mathrm{~m}$ above sea level (a.s.1.), surrounded by a series of mountain ranges with elevations from 1,500 to 3,400 m.a.s.l. Three major climatic zones can be distinguished in mainland Spain. Most of the study area (from the central plateau to the east and south) is dominated by a Mediterranean climate, characterized by seasonal temperatures, summer drought, erratic rainfall and annual precipitation between 400 and $800 \mathrm{~mm}$. A semiarid climate covers the southeastern corner of the country, defined by an extended dry season and less than $400 \mathrm{~mm}$ of annual precipitation.

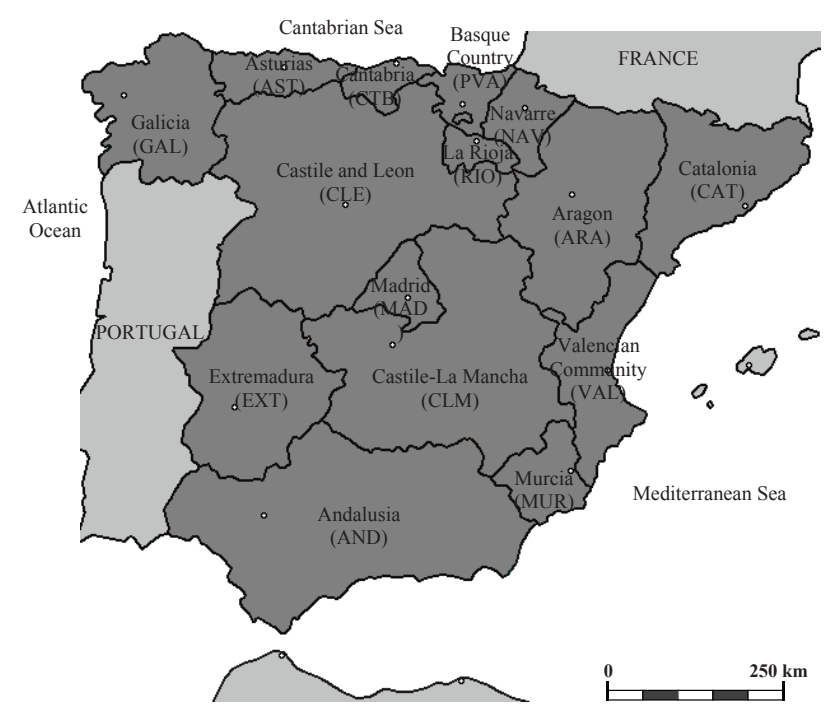

Fig. 1.- Fifteen administrative regions of mainland Spain (study area)

Finally, an oceanic climate extends through the north and northeastern portion of the country, characterized by no seasonal drought and more than $800 \mathrm{~mm}$ of annual rainfall.

\subsection{Database}

The rain gauge network provided by the Spanish Meteorological Agency (AEMET) in mainland Spain consists of more than 9,000 rainfall stations. In 1988, the R-factor at approximately 850 locations was published as part of the rainfall erosivity evaluation conducted by ICONA (1988). However, only a limited number of those stations (approximately $10 \%$ ) were actual pluviographs with complete and continuous rainfall data series over 20 years. Rainfall erosivity was found to vary widely across the country since the reported values ranged from 21 to $550 \mathrm{MJ} \cdot \mathrm{cm} \cdot \mathrm{ha}^{-1} \cdot \mathrm{h}^{-1} \cdot \mathrm{year}^{-1}$. To date, no more attempts to complete the national network have been published and the R-factor values reported by ICONA (1988) are still considered a reference for the study of rainfall erosivity in Spain.

In this study, rainfall stations were selected on the basis of geographic location, elevation, record of complete years and reported R-factor. The goal was not only to obtain a representative sample of the geography throughout mainland Spain, but also to characterize the broad rainfall erosivity range previously identified by ICONA. A total of 74 rainfall stations were chosen, which translated into approximately 4,400 annual rainfall data sets ( 74 stations times 60 years on average). For each station, monthly rainfall and maximum monthly rainfall in 24 hours were provided by AEMET. Locations of the 74 stations considered in this study are shown in Fig. 2. Table 1 includes the station name, region, elevation, available R-factor, analysis period covered and number of complete years.

Rainfall data were employed to perform a regression analysis between R-factor values reported by ICONA and the 


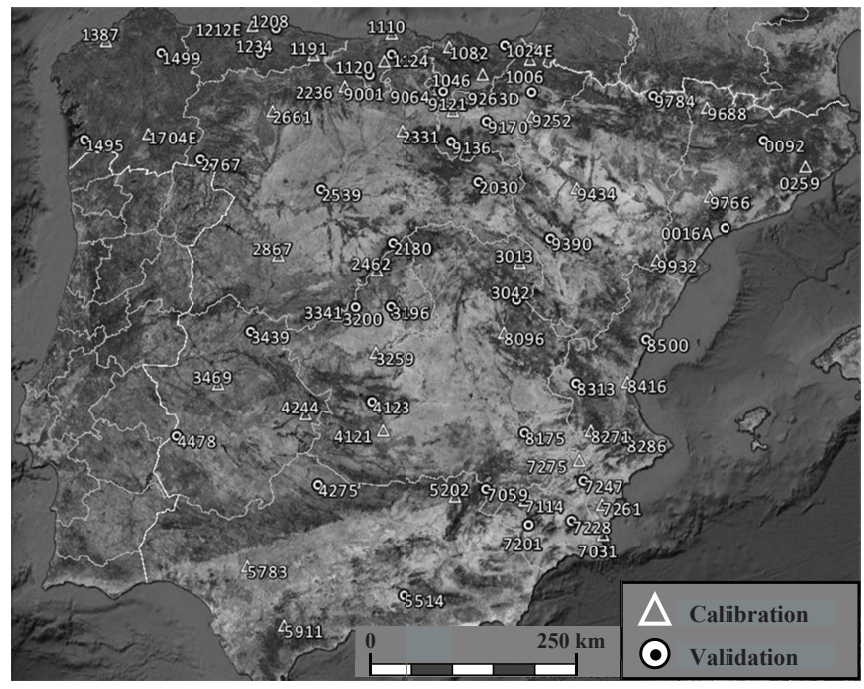

Fig. 2.- Location of selected rainfall stations

four estimators presented in Section 2.1 (R-ICONA, P, F and MFI). The regression analysis was divided into three stages:

First, 37 stations were used to develop a regression model for each estimator and record length characterizing the entire mainland Spain, i.e., a regression analysis at a global level. Models obtained from these 37 calibration stations were then validated in 37 additional stations. Both calibration and validation stations are identified in Figure 2 and Table 1.

Second, rainfall data were used to establish a regression model for each estimator and record length in each of the 15 administrative regions that compose mainland Spain, i.e., a regression analysis at a regional level. Given the relatively reduced number of rainfall stations in each region, all stations were considered for model calibration and no validation was conducted at a regional level.

Finally, results obtained at a regional level were used to discuss the applicability of a single model for estimating Rfactor throughout mainland Spain.

\subsection{Statistical models}

Two statistical models were selected for this study. The first one was a simple linear regression with intercept term, as defined by equation 8 :

$$
R=\beta_{0}+\beta_{1} \cdot X+\varepsilon
$$

where $\mathrm{R}$ is the rainfall erosivity factor, $\beta_{0}$ is the intercept term, $\beta_{1}$ is the slope, $\mathrm{X}$ is the estimator (R-ICONA, $\mathrm{P}, \mathrm{F}$ and MFI) and $\varepsilon$ represents the error.

It should be noted that the intercept term $\beta_{0}$ is just a fitting parameter which has no physical meaning since no erosion should occur for zero rainfall. Therefore, a simple linear regression through the origin (no intercept term) was defined as the second statistical model:

$$
R=\beta_{2} \cdot X+\varepsilon
$$

in which $\mathrm{R}$ is the rainfall erosivity factor, $\beta$ is the slope, $\mathrm{X}$ is the estimator and $\varepsilon$ represents the error.

The assumptions for both models were that errors are independent of each other and normally distributed with a mean of zero and constant variance. Based on available rainfall data, a series of values for each estimator (R-ICONA, P, F and MFI) and record length (1, 2, 5, 10, 15 and 20 years) were determined. These values were then correlated with the single computed R-factor reported by ICONA (1988) for each station.

\section{Results and discussion}

\subsection{Regression analysis at a global level}

\section{Model calibration}

Regression results obtained at a global level from 37 calibration stations in mainland Spain are presented in Table 2 . These results include regression equation, coefficient of determination $\left(\mathrm{r}^{2}\right)$ and root mean squared error (RMSE) for each estimator and record length. Assumptions of the statistical models were successfully validated. It was observed that the regression model through the origin (Eq. 9) provided $\mathrm{r}^{2}$ and RMSE values rather close to those provided by the regression model with intercept term (Eq. 8). In fact, the intercept term was found not to be statistically significant in the regression analysis. Therefore, the simpler regression model without intercept term was proposed in Table 2 for most record lengths and estimators.

Good results were obtained for R-ICONA, P, F and MFI; around $70 \%$ of the total variability $\left(\mathrm{r}^{2}=0.70\right)$ was explained for record lengths as short as 5 years. MFI clearly ranked first among the assessed indexes in terms of $\mathrm{r}^{2}$ and RMSE for any record length. R-ICONA and F were the worst estimators for record lengths lower than 5 years, whereas they ranged between MFI and P for record lengths of 5 years or more. The slope obtained for R-ICONA suggests that the current regression model proposed by ICONA (Eqs. 3-5) may overpredict the R-factor by approximately $19 \%$. These results support previous observations by Hernando and Romana (2015) who reported an average overestimate of $16 \%$ in the central part of Spain (Madrid Region).

\section{Effect of record length on estimate precision and accuracy}

As can be inferred from Table 2, record length had a direct effect on regression models: as record length increased, $\mathrm{r}^{2}$ increased and RMSE decreased. A possible explanation is that as record length increased, the annual values of the estimators were averaged over a longer time interval as defined by Eq. 7. Thus, this 'smoothing' effect translated into less dispersion and, consequently, a better fit.

In order to further analyze the effect of record length on the precision and accuracy of the estimates, two additional 


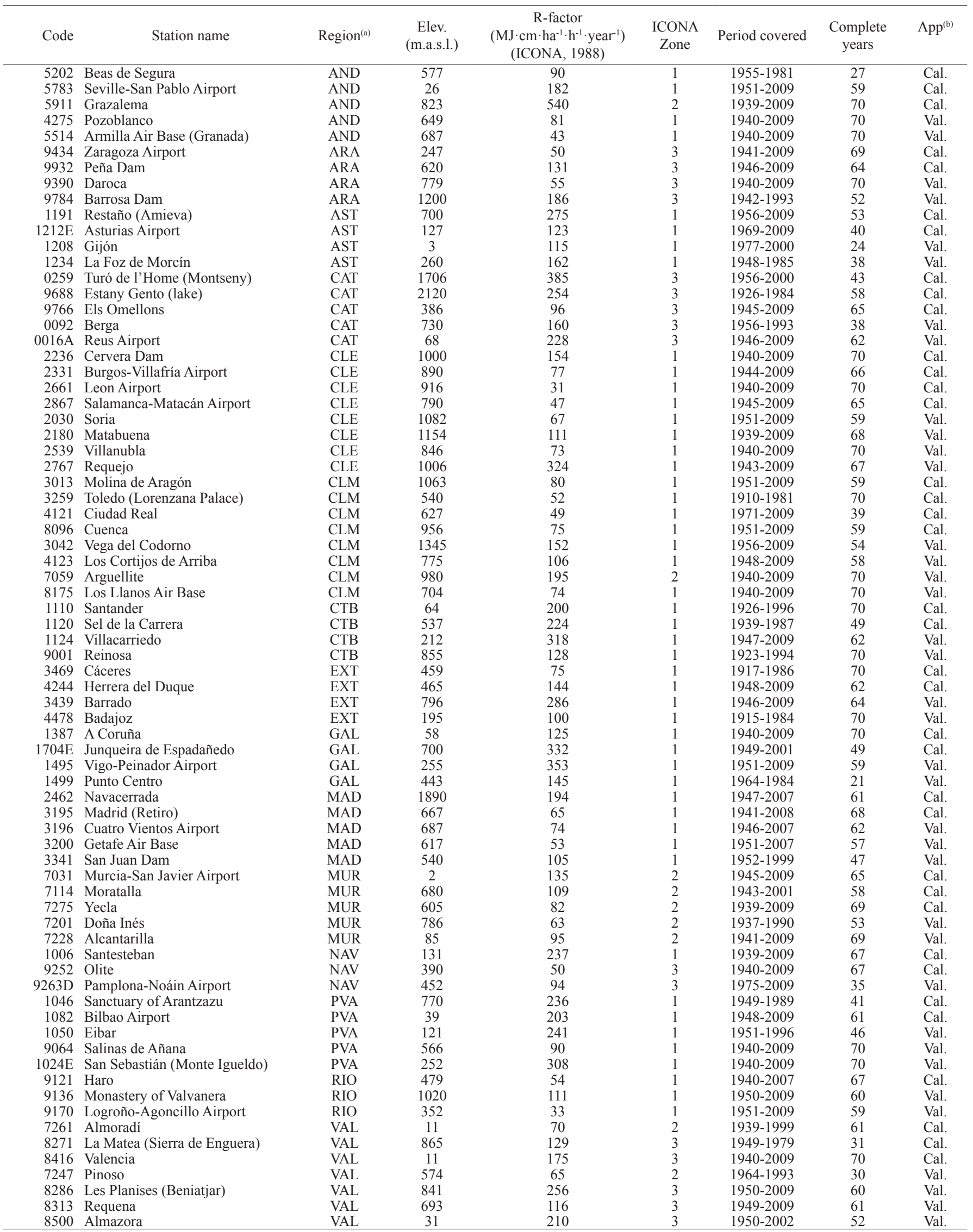

(a) $\mathrm{AND}=$ Andalusia; $\mathrm{ARA}=\mathrm{Aragon} ; \mathrm{AST}=\mathrm{Asturias} ; \mathrm{CAT}=$ Catalonia; $\mathrm{CLE}=$ Castile and Leon; $\mathrm{CLM}=$ Castile-La Mancha; $\mathrm{CTB}=\mathrm{Cantabria}$; $\mathrm{EXT}=$ Extremadura; $\mathrm{GAL}=\mathrm{Galicia} ; \mathrm{MAD}=\mathrm{Madrid}$; MUR=Murcia; NAV=Navarre; PVA=Basque Country; RIO=La Rioja; VAL=Valencian Community.

(b) Application of rain gauge station for the regression analysis at a global level: 'Cal.' denotes calibration whereas 'Val.' denotes validation.

Table 1. Characteristics of rainfall stations selected in this study 


\begin{tabular}{|c|c|c|c|}
\hline $\begin{array}{l}\text { Estimator / } \\
\text { Record length }\end{array}$ & Regression equation & $\mathrm{r}^{2}$ & $\begin{array}{c}\text { RMSE } \\
\left(\mathrm{MJ} \cdot \mathrm{cm} \cdot \mathrm{ha}^{-1} \cdot \mathrm{h}^{-1} \cdot \text { year }^{-1}\right)\end{array}$ \\
\hline \multicolumn{4}{|c|}{$\mathrm{R}_{\mathrm{ICONA}}\left(\mathrm{MJ} \cdot \mathrm{cm} \cdot \mathrm{ha}^{-1} \cdot \mathrm{h}^{-1} \cdot \mathrm{year}^{-1}\right)$} \\
\hline 1 year & $\mathrm{R}=0.32 \cdot \mathrm{R}_{\mathrm{ICONA}}+92.83$ & 0.37 & 86 \\
\hline 2 years & $\mathrm{R}=0.46 \cdot \mathrm{R}_{\mathrm{ICONA}}+70.01$ & 0.52 & 74 \\
\hline 5 years & $\mathrm{R}=0.62 \cdot \mathrm{R}_{\mathrm{ICONA}}+43.11$ & 0.71 & 58 \\
\hline 10 years & $\mathrm{R}=0.81 \cdot \mathrm{R}_{\mathrm{ICONA}}$ & 0.81 & 47 \\
\hline 15 years & $\mathrm{R}=0.82 \cdot \mathrm{R}_{\mathrm{ICONA}}$ & 0.86 & 39 \\
\hline 20 years & $\mathrm{R}=0.82 \cdot \mathrm{R}_{\mathrm{ICONA}}$ & 0.89 & 37 \\
\hline \multicolumn{4}{|c|}{ Annual rainfall, $\mathrm{P}(\mathrm{mm})$} \\
\hline 1 year & $\mathrm{R}=0.15 \cdot \mathrm{P}+25.42$ & 0.59 & 69 \\
\hline 2 years & $\mathrm{R}=0.18 \cdot \mathrm{P}$ & 0.62 & 66 \\
\hline 5 years & $\mathrm{R}=0.18 \cdot \mathrm{P}$ & 0.67 & 62 \\
\hline 10 years & $\mathrm{R}=0.18 \cdot \mathrm{P}$ & 0.69 & 60 \\
\hline 15 years & $\mathrm{R}=0.18 \cdot \mathrm{P}$ & 0.71 & 58 \\
\hline 20 years & $\mathrm{R}=0.18 \cdot \mathrm{P}$ & 0.72 & 58 \\
\hline \multicolumn{4}{|c|}{ Fournier index, F (mm) } \\
\hline 1 year & $\mathrm{R}=1.22 \cdot \mathrm{F}+86.61$ & 0.37 & 86 \\
\hline 2 years & $\mathrm{R}=1.72 \cdot \mathrm{F}+62.21$ & 0.52 & 75 \\
\hline 5 years & $\mathrm{R}=2.29 \cdot \mathrm{F}+34.35$ & 0.70 & 59 \\
\hline 10 years & $\mathrm{R}=2.80 \cdot \mathrm{F}$ & 0.76 & 53 \\
\hline 15 years & $\mathrm{R}=2.80 \cdot \mathrm{F}$ & 0.81 & 47 \\
\hline 20 years & $\mathrm{R}=2.80 \cdot \mathrm{F}$ & 0.86 & 41 \\
\hline \multicolumn{4}{|c|}{ Modified Fournier index, MFI (mm) } \\
\hline 1 year & $\mathrm{R}=0.98 \cdot \mathrm{MFI}+33.87$ & 0.62 & 67 \\
\hline 2 years & $\mathrm{R}=1.23 \cdot \mathrm{MFI}$ & 0.71 & 59 \\
\hline 5 years & $\mathrm{R}=1.28 \cdot \mathrm{MFI}$ & 0.81 & 47 \\
\hline 10 years & $\mathrm{R}=1.28 \cdot \mathrm{MFI}$ & 0.84 & 42 \\
\hline 15 years & $\mathrm{R}=1.28 \cdot \mathrm{MFI}$ & 0.87 & 39 \\
\hline 20 years & $\mathrm{R}=1.28 \cdot \mathrm{MFI}$ & 0.89 & 37 \\
\hline
\end{tabular}

Table 2. Regression results for R-factor $\left(\mathrm{MJ} \cdot \mathrm{cm} \cdot \mathrm{ha}^{-1} \cdot \mathrm{h}^{-1} \cdot \mathrm{year}^{-1}\right)$ at a global level from 37 calibration stations

statistics were evaluated: coefficient of variation $(\mathrm{CV})$ and mean absolute percentage error (MAPE). This approach was previously used by the authors (Hernando and Romana, 2015) to assess the effect of record length at a local level (regional scale). $\mathrm{CV}$ is defined as the ratio of the standard deviation to the mean of a sample, expressed as a percentage. This statistic represents the variability of an index about its mean value and indicates the precision of the estimator. MAPE is a measure of the error estimating the R-factor (i.e., accuracy) and is determined as follows:

$$
\operatorname{MAPE}(\%)=\frac{1}{N} \sum_{j=1}^{N}\left|\frac{R-\hat{R}_{j}}{R}\right|
$$

in which $\mathrm{R}$ is the known value of the R-factor (Table 1$), \hat{R}_{j}$ is the estimated value from the regression model, and $\mathrm{N}$ is the number of data points for a given record length.

Fig. 3 plots CV for each estimator and record length. As clearly shown, P and MFI were the estimators with the lowest $\mathrm{CV}$ for any record length. R-ICONA and F nearly doubled the $\mathrm{CV}$ values obtained for $\mathrm{P}$ and MFI. The overall trend of the four estimators showed a substantial decrease in CV from 1 to 5 years of record length, followed by a slight reduction over 10 years.

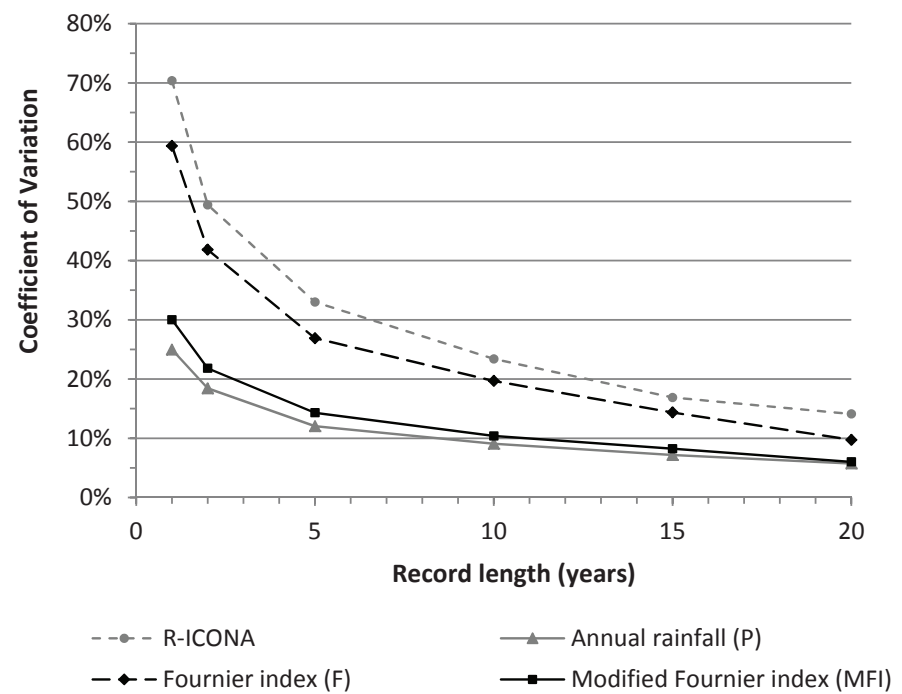

Fig. 3.- Coefficient of variation for each estimator and record length (global model calibration)

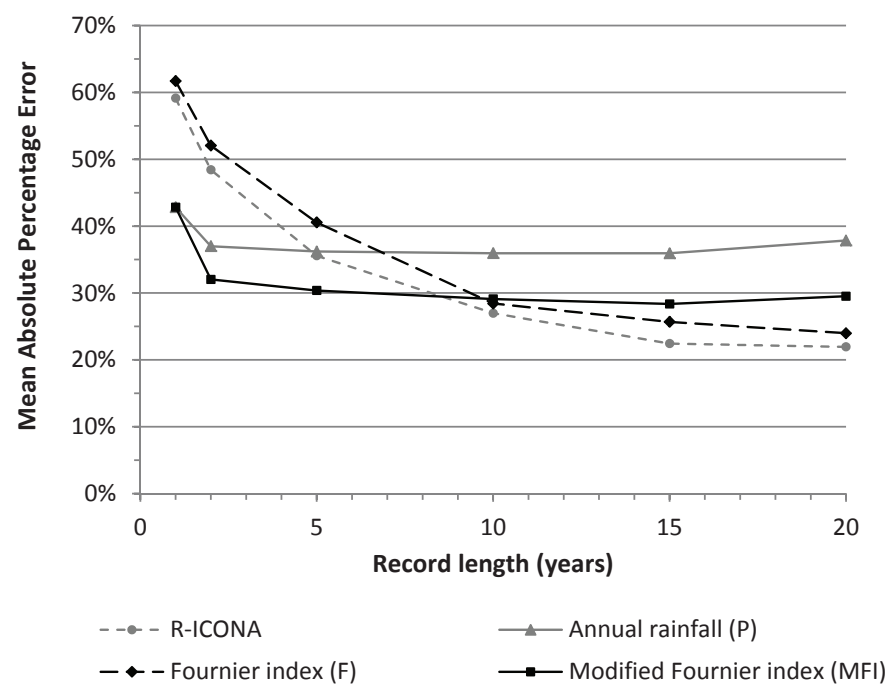

Fig. 4.- Mean absolute percentage error for each estimator and record length (global model calibration)

As depicted in Fig. 4, the overall trend of MAPE was clearly different from that of CV. P and MFI initially showed a moderate decrease in MAPE, but the values quickly leveled out at $30-35 \%$ for record lengths over 2 years. As for R-ICONA and F, a steep decline in MAPE was observed up to 10 years, followed by a small decrease for record lengths over 10 years.

These results confirmed that record length increased both precision and accuracy of the estimates when time intervals up to 10 years were considered, but slight improvement was obtained beyond that. A record length of 10 years seemed adequate to estimate the R-factor in mainland Spain at a global level. Therefore, regression results in Table 2 were reduced to one single equation for each estimator, as summarized in Table 3. 


\begin{tabular}{lcccccc}
\hline Estimator & $\begin{array}{c}\text { Record } \\
\text { length }\end{array}$ & $\begin{array}{c}\text { Regression } \\
\text { equation }\end{array}$ & $\mathrm{r}^{2}$ & $\begin{array}{c}\mathrm{RMSE} \\
\left(\mathrm{MJ} \cdot \mathrm{cm}^{-1} \mathrm{ha}^{-1} \cdot \mathrm{h}^{-1} \cdot \text { year }^{-1}\right)\end{array}$ & $\begin{array}{c}\mathrm{CV} \\
(\%)\end{array}$ & $\begin{array}{c}\text { MAPE } \\
(\%)\end{array}$ \\
\hline $\mathrm{R}_{\mathrm{ICONA}}$ & 10 years & $\mathrm{R}=0.81 \cdot \mathrm{R}_{\mathrm{ICONA}}$ & 0.81 & 47 & 23 & 27 \\
$\mathrm{P}$ & 10 years & $\mathrm{R}=0.18 \cdot \mathrm{P}$ & 0.69 & 60 & 9 & 36 \\
$\mathrm{~F}$ & 10 years & $\mathrm{R}=2.80 \cdot \mathrm{F}$ & 0.76 & 53 & 20 & 28 \\
$\mathrm{MFI}$ & 10 years & $\mathrm{R}=1.28 \cdot \mathrm{MFI}$ & 0.84 & 42 & 10 & 29 \\
\hline
\end{tabular}

Table 3. Simplified regression models obtained from 37 calibration stations (global analysis)

\section{Validation}

The simplified regression models obtained from 37 calibration stations (Table 3 ) were used to estimate the R-factor in 37 additional stations. Results are illustrated in Fig. 5, in which the vertical axis represents measured R-factor reported by ICONA (Table 1) and the horizontal axis represents predicted R-factor. The four estimators provided acceptable results for the proposed record length of 10 years. Overall, a good fit was observed for R-factor values under $200 \mathrm{MJ} \cdot \mathrm{cm} \cdot \mathrm{ha}^{-1} \cdot \mathrm{h}^{-1} \cdot$ year $^{-1}$, while some scattered data points appeared above this value, especially for R-ICONA and F.

RMSE and MAPE were also evaluated in the validation stations. Fig. 6 shows that RMSE values obtained from validation were rather close to those previously obtained from calibration, except for R-ICONA, which experienced a moderate increase. MFI was the estimator with the lowest RMSE. Regarding MAPE, Fig. 7 indicates that validation results were fairly similar to those observed from calibration. $\mathrm{F}$ and MFI showed the lowest MAPE values (25\%).
These results clearly showed that MFI was the best estimator of the R-factor at a global level in mainland Spain. The simple regression equation:

$$
R=1.28 \cdot M F I_{10}
$$

in which $\mathrm{R}$ is the rainfall erosivity factor $\left(\mathrm{MJ} \cdot \mathrm{cm} \cdot \mathrm{ha}^{-1} \cdot \mathrm{h}\right.$ ${ }^{1} \cdot$ year $^{-1}$ ) and $\mathrm{MFI}_{10}$ is the modified Fournier index (mm) for a 10-year record length, not only yielded the best calibration results compared to the other estimators, but also minimized both RMSE and MAPE in the validation analysis.

\subsection{Regression analysis at a regional level}

A regression analysis was independently conducted for each of the 15 administrative regions that compose mainland Spain. Regression models at a regional level were developed for each estimator and record length following the procedure described in Section 3.1. One single regression equation was then selected for each region, based on the combined analysis of $r^{2}$, RMSE, CV and MAPE. Regression results are summarized in Table 4.

As shown in Table 4, excellent results in terms of $r^{2}$ were obtained in all regions $(87 \%$ of total variability explained on average). The intercept term was again found not to be statistically significant, so regression models through the origin were chosen. Selected record lengths varied from 5 to 20 years, with the longest record lengths consistently located in the eastern part of the country (Catalonia, Valencian Community, Murcia and Castile-La Mancha). Eastern Spain is known for a marked erratic rainfall pattern, which may explain why
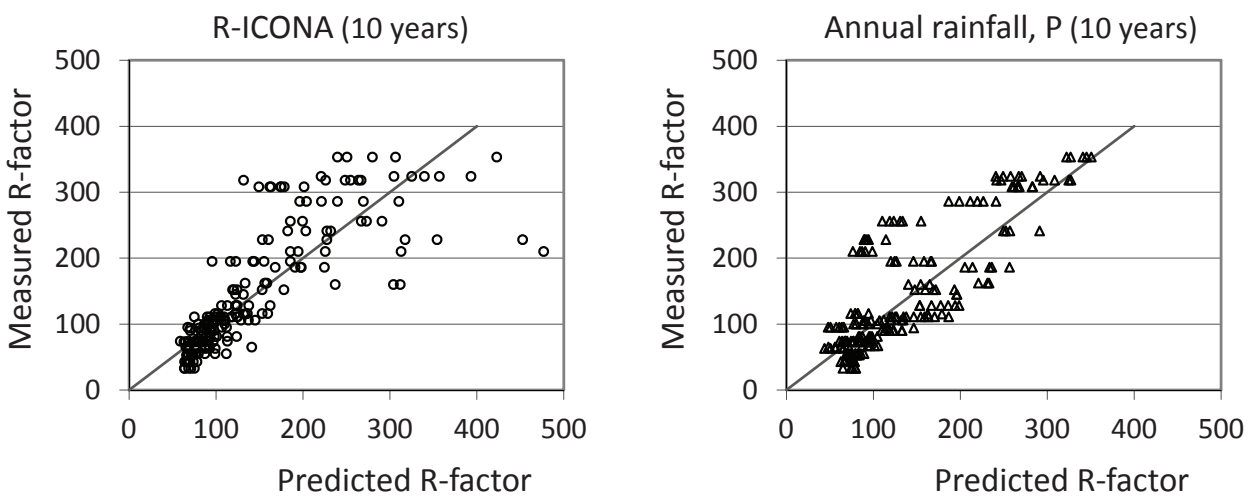

Fig. 5.- Scatter plot of R-factor measured by ICONA vs. R-factor predicted by estimates for proposed record length (10 years) in $\mathrm{MJ} \cdot \mathrm{cm} \cdot \mathrm{ha}^{-1} \cdot \mathrm{h}^{-1} \cdot$ year $^{-1}$ (global model validation)
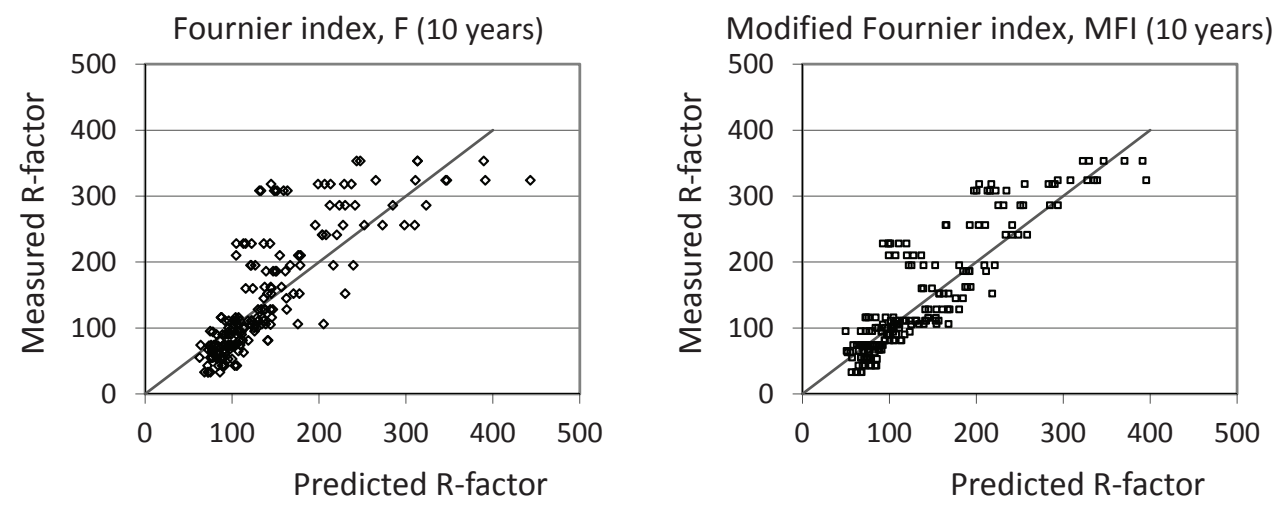


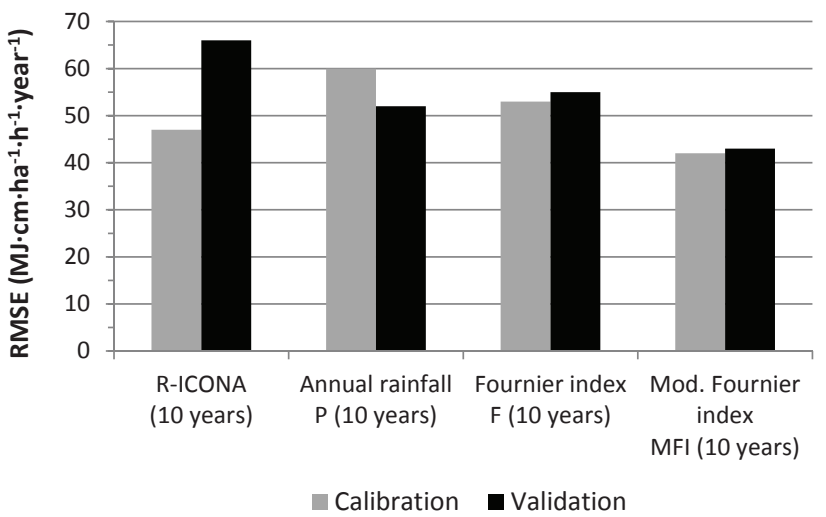

Fig. 6.- Comparison of root mean squared error (RMSE) results for calibration and validation (global model)

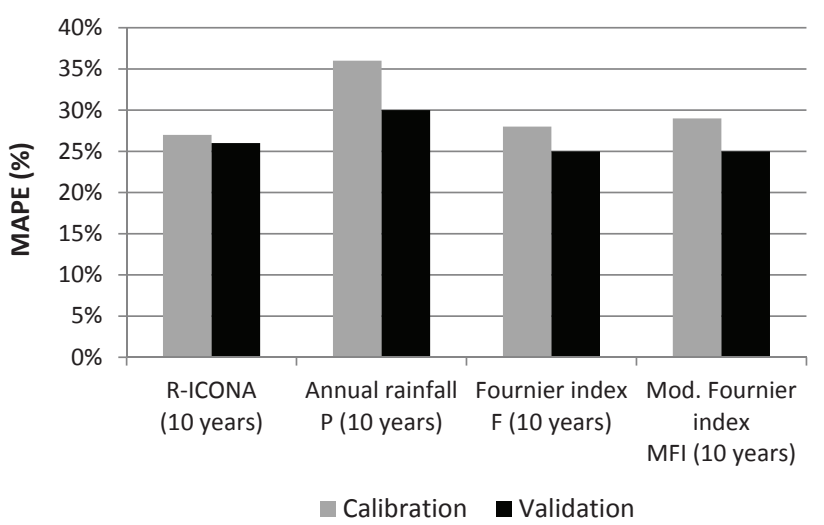

Fig. 7.- Comparison of mean absolute percentage error (MAPE) results for calibration and validation (global model)

a short record length did not provide an adequate estimate of the long-term rainfall erosivity. Outcomes from regression analysis showed that MFI was the best performing estimator in most regions (9 out of 15). P was chosen at four northern regions, characterized by a relatively high annual rainfall. These results are supported by Ferro et al. (1999), who previously reported that $\mathrm{P}$ was a robust estimator of the R-factor in regions where high rainfall erosivity corresponded to high annual rainfall. F was only selected at two of the eastern regions. The average CV value ( $10 \%)$ was exactly the same obtained at a global level, whereas the average MAPE value of $18 \%$ was substantially lower than that determined from global analysis (28\%). Because of the relatively reduced number of stations in each region, all stations were used for model development and no validation analysis was conducted at the regional level.

\subsection{Applicability of a single (global) estimate model}

\section{Result comparison}

Results obtained at the regional level were used in this section to discuss the applicability of a single (global) model for estimating the R-factor across mainland Spain. Fig. 8 plots the slope of the regression through the origin obtained for

\begin{tabular}{|c|c|c|c|c|c|c|}
\hline Region & $\begin{array}{l}\text { Record } \\
\text { length }\end{array}$ & $\begin{array}{l}\text { Regression } \\
\text { equation }\end{array}$ & $r^{2}$ & $\begin{array}{c}\text { RMSE } \\
\left(\mathrm{MJ} \cdot \mathrm{cm}^{-1} \mathrm{ha}^{-1} \cdot \mathrm{h}^{-1} \cdot \text { year }^{-1}\right)\end{array}$ & $\begin{array}{l}\text { CV } \\
(\%)\end{array}$ & $\begin{array}{c}\text { MAPE } \\
(\%)\end{array}$ \\
\hline AND & 10 years & $\mathrm{R}=1.27 \cdot \mathrm{MFI}$ & 0.97 & 37 & 10 & 33 \\
\hline ARA & 5 years & $\mathrm{R}=1.22 \cdot \mathrm{MFI}$ & 0.84 & 21 & 15 & 20 \\
\hline AST & 5 years & $\mathrm{R}=1.18 \cdot \mathrm{MFI}$ & 0.82 & 30 & 9 & 14 \\
\hline CAT & 20 years & $\mathrm{R}=4.79 \cdot \mathrm{F}$ & 0.92 & 28 & 5 & 16 \\
\hline CLE & 5 years & $\mathrm{R}=1.14 \cdot \mathrm{MFI}$ & 0.88 & 30 & 12 & 35 \\
\hline CLM & 20 years & $\mathrm{R}=1.18 \cdot \mathrm{MFI}$ & 0.82 & 22 & 7 & 17 \\
\hline СТВ & 15 years & $\mathrm{R}=0.16 \cdot \mathrm{P}$ & 0.79 & 33 & 7 & 13 \\
\hline EXT & 5 years & $\mathrm{R}=1.29 \cdot \mathrm{MFI}$ & 0.84 & 32 & 16 & 20 \\
\hline GAL & 10 years & $\mathrm{R}=1.25 \cdot \mathrm{MFI}$ & 0.88 & 38 & 9 & 16 \\
\hline MAD & 5 years & $\mathrm{R}=1.05 \cdot \mathrm{MFI}$ & 0.93 & 14 & 11 & 11 \\
\hline MUR & 20 years & $\mathrm{R}=2.93 \cdot \mathrm{F}$ & 0.84 & 10 & 11 & 9 \\
\hline NAV & 5 years & $\mathrm{R}=0.14 \cdot \mathrm{P}$ & 0.94 & 22 & 12 & 20 \\
\hline PVA & 10 years & $\mathrm{R}=0.17 \cdot \mathrm{P}$ & 0.80 & 36 & 7 & 16 \\
\hline RIO & 5 years & $\mathrm{R}=0.11 \cdot \mathrm{P}$ & 0.88 & 11 & 11 & 19 \\
\hline \multirow[t]{2}{*}{ VAL } & 20 years & $\mathrm{R}=1.71 \cdot \mathrm{MFI}$ & 0.81 & 30 & 10 & 21 \\
\hline & & Average & 0.87 & 26 & 10 & 18 \\
\hline
\end{tabular}

Table 4. Regression models proposed for mainland Spain (regional analysis)

each estimator and region (note that Section 3.2 only presented the slope for the selected estimator). For comparative purposes, a constant record length of 20 years was considered for all regions. Regions were sorted by slope from smallest to largest. In addition, the slope previously determined from the global analysis is depicted in Fig. 8 as a horizontal line.

As can be seen in Fig. 8, Catalonia, Valencian Community and Murcia, three contiguous regions of Eastern Spain, seemed to provide extreme slope values for the four estimators, which could be an indication of a different rainfall erosivity pattern. These three regions had the highest slope coefficients for both P and MFI. In addition, Catalonia presented the highest slope for F, and both Valencian Community and Catalonia were two of the regions with the lowest slope for R-ICONA. A closer look at the initial regression model at a global level (Fig. 5) revealed that most of the discordant rainfall stations identified for rainfall erosivity values over $200 \mathrm{MJ} \cdot \mathrm{cm} \cdot \mathrm{ha}^{-1} \cdot \mathrm{h}^{-1} \cdot$ year $^{-1}$ happened to be located in this three regions. These observations were supported by an analysis of the variance (ANOVA), which confirmed that the values obtained in Catalonia, Valencian Community and Murcia were statistically different from those obtained in the rest of mainland Spain, for a significance level of 5\%. After this important finding, the decision was to conduct a new regression analysis by dividing mainland Spain into two areas (Fig. 9):

a) Eastern Spain, composed of Catalonia, Valencian Community and Murcia; and b) Plateau-lowland area, which included the rest of mainland Spain.

\section{Bi-areal regression model}

Regression equations were developed in both areas for each estimator and record length. Calibration and validation stations previously used for the initial regression analysis at 
a) R-ICONA

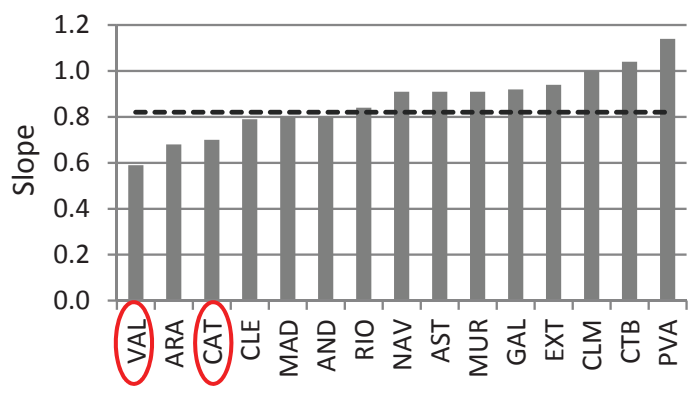

c) Fournier index (F)

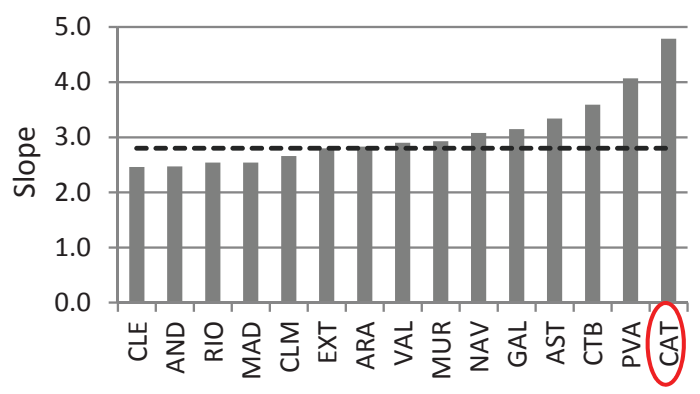

b) Annual rainfall (P)

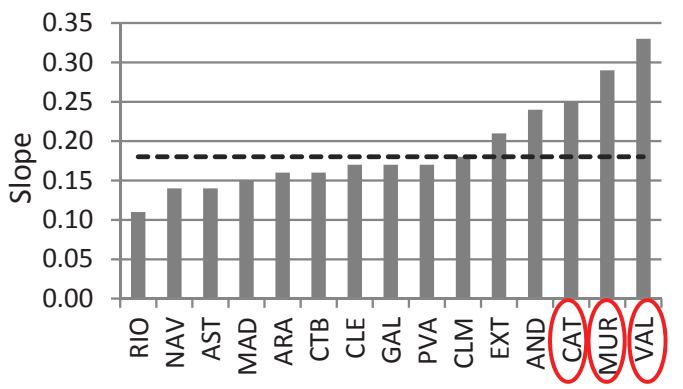

d) Modified Fournier index (MFI)

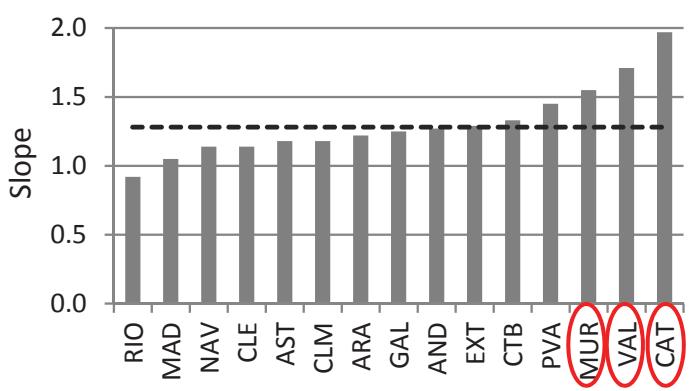

Fig. 8.- Slope coefficients obtained for regressions through the origin from analysis at the regional level (20-year record length)
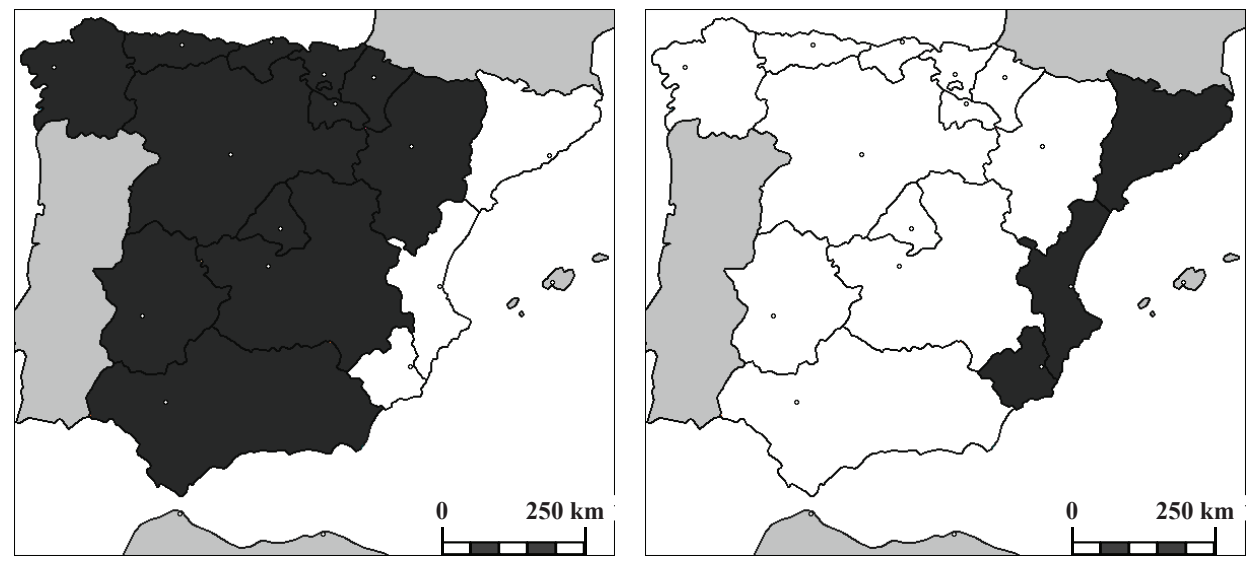

Fig. 9.- Areas defined for bi-areal regression model: Plateau-lowland area (left); Eastern Spain (right)

a global level were respectively maintained for the two new areas into which mainland Spain was divided. This means that 28 calibration stations and 29 validation stations were used for the Plateau-lowland area, while 9 stations were used for calibration and 8 for validation in Eastern Spain (Table 1, Fig. 2). A record length of 10 years was selected based on the analysis of $\mathrm{r}^{2}$, RMSE, CV and MAPE results from the calibration stations. Validation results confirmed that MFI outperformed the rest of estimators in both areas. The regression equation obtained for each area is as follows:

Plateau-lowland: $\quad \mathrm{R}=1.22 \cdot M F I_{10}$

Eastern Spain: $\quad \mathrm{R}=1.80 \cdot M F I_{10}$ where $\mathrm{R}$ is the rainfall erosivity factor $\left(\mathrm{MJ} \cdot \mathrm{cm} \cdot \mathrm{ha}^{-1} \cdot \mathrm{h}\right.$ ${ }^{1}$. year $\left.^{-1}\right)$ and $\mathrm{MFI}_{10}$ is the modified Fournier index $(\mathrm{mm})$ for a 10 -year record length. Compared to the single (global) model, the slope coefficient for the Plateau-lowland area slightly decreased from 1.28 to 1.22, whereas the slope for Eastern Spain experienced a substantial increase to 1.80. An increase in the slope coefficient for Eastern Spain was expected, since most of the rainfall stations from this area fell above the identity line defined in Fig. 5.

Results of $\mathrm{r}^{2}$, RMSE, CV and MAPE for the bi-areal model proposed in this section (Plateau-lowland and Eastern Spain) were compared to those previously obtained for the global model in Section 3.1. Fig. 10 shows a significant improvement in the variability explained by the regression model 

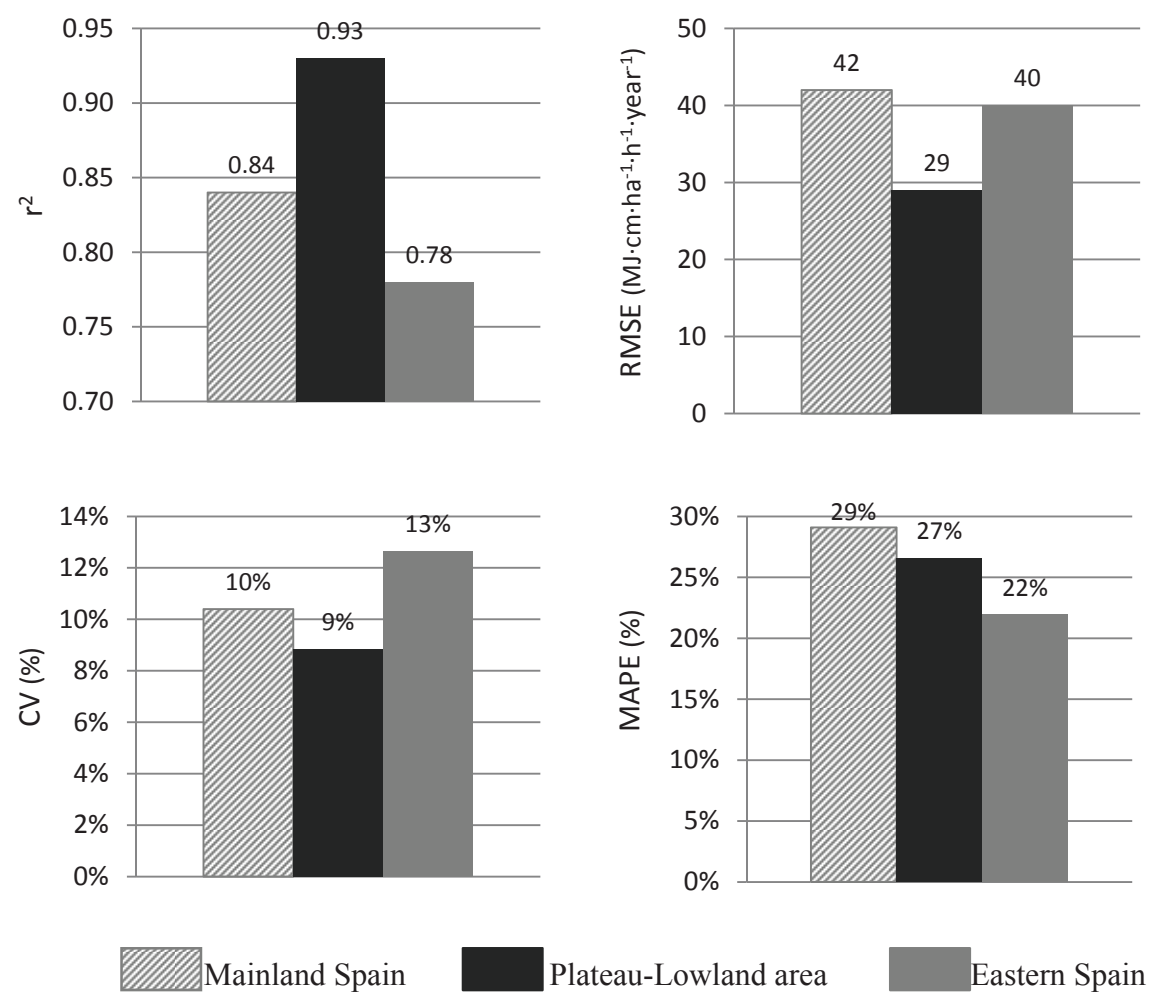

Fig. 10.- Comparison of $\mathrm{r}^{2}$, RMSE, CV and MAPE results for the single and the bi-areal models (Plateau-Lowland area and Eastern Spain) in mainland Spain when the Plateau-lowland area was studied independently of Eastern Spain ( $\mathrm{r}^{2}$ increased from 0.84 to 0.93 ). However, $\mathrm{r}^{2}$ for Eastern Spain decreased moderately. As previously stated, this area is characterized by a strong erratic rainfall pattern, which means higher variability in rainfall erosivity. In fact, this higher variability was observed by an increase in $\mathrm{CV}$ from 10 to $13 \%$. At this point, it was not clear whether the division of mainland Spain into two areas (bi-areal model) really provided better estimates as compared to the single model. However, the analysis of RMSE and MAPE clearly showed improvement. The original RMSE of $42 \mathrm{MJ} \cdot \mathrm{cm} \cdot$ ha ${ }^{1} \cdot \mathrm{h}^{-1} \cdot$ year ${ }^{-1}$ obtained for the global model was reduced to 40 $\mathrm{MJ} \cdot \mathrm{cm} \cdot \mathrm{ha}^{-1} \cdot \mathrm{h}^{-1} \cdot$ year $^{-1}$ in Eastern Spain and, especially, to 29 $\mathrm{MJ} \cdot \mathrm{cm} \cdot \mathrm{ha}^{-1} \cdot \mathrm{h}^{-1} \cdot$ year $^{-1}$ in the Plateau-lowland area $(31 \% \mathrm{re}-$ duction). Furthermore, RMSE decreased from $29 \%$ for the global model to $27 \%$ for the Plateau-lowland area and $22 \%$ for Eastern Spain. Therefore, these results confirmed that the rainfall erosivity pattern of Eastern Spain is different from that of the Plateau-lowland area, and the use of the bi-areal model clearly improves the estimate of the R-factor in mainland Spain.

\subsection{Validation of the regression model proposed by ICONA}

The regression model proposed by ICONA (Eqs. 3-5) was validated by computing R-ICONA in the 74 rainfall stations considered in this study. A regression model was then established between R-ICONA and the reported values of the $\mathrm{R}$-factor. The parameter used for validation analysis was the slope obtained from the regression-through-the-origin model.
Since the R-factor represents the long-term average value of rainfall erosivity, a record length of 20 years was assumed to be the most representative for this analysis.

Fig. 11 depicts the relationship between R-ICONA (in the horizontal axis) and reported $\mathrm{R}$-factor (in the vertical axis) for 74 rainfall stations in mainland Spain. It was found that most of the points fell below the identity line, which indicated the regression model proposed by ICONA overpredicted the R-factor. A slope of 0.81 was obtained for the regression through the origin, which meant an overall overprediction of $19 \%$. Note that Fig. 8.a depicts how the slope of the regression between R-ICONA and R-factor varied from region to region. From this figure one can see that only Castile-La Mancha presented a slope value close to 1.0. Cantabria and Basque Country yielded slope values above 1.0, while slope coefficients below 1.0 were obtained in most of mainland Spain (12 out of 15 regions).

\section{Summary and conclusions}

A detailed linear regression analysis of 74 rainfall stations throughout mainland Spain resulted in the identification and validation of a readily available estimate of the (R)USLE rainfall erosivity factor. The conducted analysis clearly showed the modified Fournier index (MFI) ranked first among the assessed indexes. In an initial attempt to provide a simple estimate of the R-factor, a single global regression equation was developed for mainland Spain. Thirty-seven calibration stations showed that MFI provided the best results in terms of coefficient of determination $\left(\mathrm{r}^{2}\right)$ and root mean squared er- 


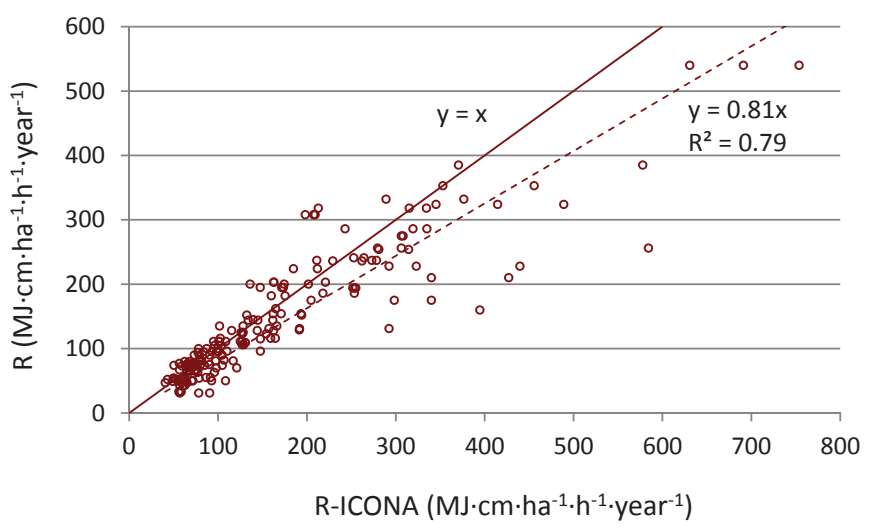

Fig. 11.- Scatter plot of R-factor vs. R-ICONA for 74 rainfall stations in mainland Spain

ror (RMSE). Two additional statistics, coefficient of variation (CV) and mean absolute percentage error (MAPE), were used to evaluate the effect of record length on estimate precision and accuracy. A record length of 10 years seemed to provide adequate estimates, since little improvement was obtained for longer records. Subsequently, the regression equation obtained for a 10-year record length was subjected to a validation analysis in 37 additional rainfall stations. Validation results confirmed MFI as the best estimator.

After these preliminary results at a global level, an individual regression analysis was conducted in each of the fifteen administrative regions that compose mainland Spain. The purpose of the regional analysis was to discuss the applicability of a single (global) estimate across mainland Spain. It was determined that three contiguous regions of Eastern Spain (Catalonia, Valencian Community and Murcia) consistently presented extreme slope values for the regression equations, which could indicate a different rainfall erosivity pattern. A further investigation of the global regression model revealed that most of the discordant data points happened to be located within these three regions. After this finding, a new regression analysis was conducted by dividing mainland Spain into two areas: Eastern Spain (containing Catalonia, Valencia Community and Murcia) and Plateau-lowland area (remaining regions of mainland Spain). The following equation was selected for each region:

$$
\begin{array}{ll}
\text { Plateau-lowland: } & \mathrm{R}=1.22 \cdot M F I_{10} \\
\text { Eastern Spain: } & \mathrm{R}=1.80 \cdot M F I_{10}
\end{array}
$$

in which $\mathrm{R}$ is the rainfall erosivity factor $\left(\mathrm{MJ} \cdot \mathrm{cm} \cdot \mathrm{ha}^{-1} \cdot \mathrm{h}\right.$ ${ }^{1}$. year ${ }^{-1}$ ) and $\mathrm{MFI}_{10}$ is the modified Fournier index (mm) for a 10-year record length. Results of $\mathrm{r}^{2}$, RMSE, CV and MAPE obtained for the bi-areal model were compared to those provided by the preliminary global equation. Unclear results were obtained from $\mathrm{r}^{2}$ and $\mathrm{CV}$. On the contrary, RMSE and MAPE clearly produced better results for the bi-areal model. Therefore, it was concluded that a bi-areal regression model based on MFI for a record length of 10 years provided a simple, precise and accurate estimate of the (R)USLE rainfall erosivity factor in mainland Spain.

Finally, the regression model proposed by ICONA was evaluated by estimating the $\mathrm{R}$-factor in 74 rainfall stations. It was found that R-ICONA overpredicted the rainfall erosivity factor in almost all regions, obtaining an average overprediction of $19 \%$. Thus, the bi-areal regression model developed in this study seemed to be the superior choice to estimate the rainfall erosivity factor in mainland Spain.

\section{References}

Angulo-Martínez, M., Beguería, S. (2009): Estimating rainfall erosivity from daily precipitation records: a comparison among methods using data from the Ebro Basin (NE Spain). Journal of Hydrology 379, 111-121. doi: 10.1016/j.jhydrol.2009.09.051.

Arnoldus, H.M.J. (1980): An approximation of the rainfall factor in the Universal Soil Loss Equation. In: De Boodt, M., Gabriels, D. (eds.), Assessment of Erosion. John Wiley \& Sons, Chichister, 127-132.

Bonilla, C.A., Vidal, K.L. (2011): Rainfall erosivity in Central Chile. Journal of Hydrology 410 (1-2), 126-133. doi:10.1016/j.jhydrol.2011.09.022.

Brown, L.C., Foster, G.R. (1987): Storm erosivity using idealized intensity distributions. Transactions of the American Society of Agricultural Engineers (ASAE) 30 (2), 379-386.

Colotti, E. (2004): Aplicabilidad de los datos de lluvia horaria en el cálculo de la erosidad. [Applicability of hourly rainfall data to erosion analysis]. Fondo Editorial de Humanidades y Educación. Departamento de Publicaciones. Universidad Central de Venezuela. (In Spanish).

Diodato, N. (2004): Estimating RUSLE's rainfall factor in the part of Italy with a Mediterranean rainfall regime. Hydrology and Earth System Sciences 8 (1), 103-107.

Diodato, N., Bellochi, G. (2007): Estimating monthly (R)USLE climate input in a Mediterranean region using limited data. Journal of Hydrology 345, 224-236. doi:10.1016/j.jhydrol.2007.08.008.

Ferro, V., Giordano, G., Iovino, M. (1991): Isoerosivity and erosion risk map for Sicily. Hydrological Sciences Journal 36 (6), 549-564. doi:10.1080/02626669109492543.

Ferro, V., Porto, P., Yu, B. (1999): A comparative study of rainfall erosivity estimation for southern Italy and southeastern Australia. Hydrological Sciences Journal 44 (1), 3-24. doi:10.1080/02626669909492199.

Fournier, F. (1960): Climat et érosion. La relation entre l'érosion du sol par l'eau et les précipitations atmosphériques. [Relationship between soil erosion by water and rainfall] Presses Universitaires de France, Paris. (In French).

Hernando, D., Romana, M.G. (2015): Estimating the rainfall erosivity factor from monthly precipitation data in the Madrid Region (Spain). Journal of Hydrology and Hydromechanics 63 (1), 55-62. doi: 10.1515/johh-2015-0003.

Hudson, N. (1971): Soil Conservation. Cornell University Press, Ithaca. ICONA. (1988): Agresividad de la lluvia en España. Valores del factor $R$ de la Ecuación Universal de Pérdidas de Suelo. [Rainfall erosivity in Spain. R-factor values for the Universal Soil Loss Equation]. Ministerio de Agricultura, Pesca y Alimentación, Madrid. (In Spanish).

Lal, R. (1976): Soil erosion on alfisols in Western Nigeria III-Effects of rainfall characteristics. Geoderma 16, 389-401. doi:10.1016/00167061(76)90003-3.

Lee, J.H., Heo, J.H. (2011): Evaluation of estimation methods for rainfall erosivity based on annual precipitation in Korea. Journal of Hydrology 409 (1-2), 30-48. doi:10.1016/j.jhydrol.2011.07.031. 
Loureiro, N., Coutinho, M. (2001): A new procedure to estimate the RUSLE $\mathrm{EI}_{30}$ index, based on monthly rainfall data and applied to the Algarve region, Portugal. Journal of Hydrology 250 (1-4), 12-18. doi:10.1016/S0022-1694(01)00387-0.

Oliver, J.E. (1980): Monthly precipitation distribution: a comparative index. Professional Geographer 32(3), 300-309.

Onchev, N.G. (1985): Universal index for calculating rainfall erosivity. In: El-Swaify, S.A., Moldenhauer, W.C., Lo, A. (eds.), Soil Erosion and Conservation. Soil Conservation Society of America, Ankeny, 424-431.

Petkovšek, G., Mikoš, M. (2004): Estimating the R factor from daily rainfall data in the sub-Mediterranean climate of southwest Slovenia. Hydrological Sciences Journal 49 (5), 869-877. doi:10.1623/ hysj.49.5.869.55134.

Renard, K.G., Foster, G.R., Weesies, G.A., Porter, J.P. (1991): RUSLE - Revised Universal Soil Loss Equation. Journal of Soil and Water Conservation 46 (1), 30-33.

Renard, K.G., Foster, G.R., Weesies, G.A., McCool, D.K., Yoder, D.C. (1997): Predicting soil erosion by water: a guide to conservation planning with the revised Universal Soil Loss Equation (RUSLE). Agriculture Handbook No. 703. U.S. Department of Agriculture, Washington D.C.

Renard, K.G., Freimund, J.R. (1994): Using monthly precipitation data to estimate the R-factor in the revised USLE. Journal of Hydrology 157, 287-306. doi:10.1016/0022-1694(94)90110-4.
Salako, F.K. (2008): Rainfall variability and kinetic energy in Southern Nigeria. Climatic Change 86, 151-164. doi:10.1007/s10584-0069198-z.

Smithen, A.A., Schulze, R.E. (1982): The spatial distribution in Southern Africa of rainfall erosivity for use in the Universal Soil Loss Equation. Water SA 8 (2), 74-78.

Wischmeier, W.H. (1959): A rainfall erosion index for a Universal SoilLoss Equation. Soil Science Society of America, Proceedings 23 (3), 246-249.

Wischmeier, W.H., Smith, D.D. (1961): A universal equation for predicting rainfall-erosion losses - An aid to conservation farming in humid regions. ARS Special Report 22-66. U.S. Department of Agriculture, Washington, D.C.

Wischmeier, W.H., Smith, D.D. (1965): Predicting rainfall erosion losses from cropland East of the Rocky Mountains. Agriculture Handbook No. 282. U.S. Department of Agriculture, Washington, D.C.

Wischmeier, W.H., Smith, D.D. (1978): Predicting rainfall erosion losses. A guide to conservation planning. Agriculture Handbook No. 537. U.S. Department of Agriculture, Washington, D.C.

Yu, B., Rosewell, C.J. (1996): A robust estimator of the R factor for the Universal Soil Loss Equation. Transactions of the American Society of Agricultural Engineers (ASAE) 39, 559-561.

Yu, B., Hashim, G.M., Eusof, Z. (2001): Estimating the R-factor with limited rainfall data: a case study from peninsular Malaysia. Journal of Soil and Water Conservation 56(2), 101-105. 